\title{
対称渦による円柱の流れ方向の流力振動 \\ Flow-Induced Streamwise Oscillations of Circular Cylinders due to Symmetrical Vortices
}

岡島 厚*

Atsushi OKAJIMA

\section{1. 緒論}

一様流中の円柱に生じる流力振動、特に流れ方向流力振 動（Streamwise Oscillation, In-line Oscillation）は、カルマン 渦のような交互渦によって誘起される振動のほかに、低流 速域において一様流の軸に対して対称に形成される渦に よって励振が生じる。本報では、自由振動や強制振動して いる円柱の近傍に形成される対称渦に注目して渦構造と 円柱の流れ方向流力振動について述べる。

一様流中で円柱を流れ方向に強制加振すると円柱近傍 に形成される対称渦はロックイン現象を起す。Griffin と Hall ${ }^{1}$ は、 $f_{c} / f_{k}=2$ 付近 ( $f_{c}$ は振動円柱の振動数、 $f_{k}$ は静止 円柱後流の渦放出周波数) で円柱近傍に形成される対称渦 の周波数 $f_{w}$ が強制加振振動数 $f_{c}$ にロックインする流速域 は応答振幅に依存する。一方、King ら ${ }^{2)}$ は水槽により円柱 の流れ方向流力振動を調べ、換算流速 $V r\left(=U /\left(f_{c} d\right) 、 U\right.$ は一様流速、 $d$ は円柱の直径) が 1 2.5 の範囲と 2.6 3.6 の範囲で二つの励振域が生じることを示し、前者の領域で は刘称渦が形成され、後者の領域では交互渦によって励振 することを見出した。さらに、振動特性と対称渦の密接な 関係についての興味ある研究として、Naudasher ${ }^{3}$ の解説に よって紹介された Aguirre ${ }^{4}$ の流れ方向の流力振動の発生 機構に関する水路実験がある。後流の息づき（ wakebreathing）運動による対称渦の流れパターン変化と Movement-Induced Excitation の関連を詳細に言及している。

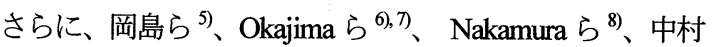
ら 9 は、風洞や回流水槽によりスクルートン数 (換算減衰
率)、 $C n=2 m \delta / \rho d^{2}$ ( $m$ は円柱の単位長さあたりの質量、 $\rho$ は流体の密度、 $\delta$ は円柱の対数减衰率) に対する円柱の 振動特性などを詳細に調べ、2 次元円柱やアスペクト比 $A R$ ( $=L / d 、 L$ はスパン方向長さ) が 21 のような長い有限 スパン長円柱では二つの励振域が生じるが、実際の温度計 のようにアスペクト比が 5 や 10 のようにスパン長さが短 い場合には一つの励振域のみ生じ、アスペクト比の小さい ほど対称渦による振動の振幅が増大することを見出した。 また、中村ら ${ }^{91}$ は、有限スパン長円柱の流れ方向の流力振 動特性と対称渦との関係に注目して、振動円柱の渦構造の スパン方向変化を調べて、励振機構と有限端の影響を明ら かにした。さらに下流にスプリッター板を挿入して振動す る円柱近傍の後流渦構造を詳細に調べた。同様な下流域に 挿入された物体の効果は、直列に配置された 2 円柱の場合、 狭い間隔の上流側円柱の流力特性に顕著である。直列 2 円 柱の上流側円柱 ${ }^{10}$ は、低い流速領域で後流の息づき (wake-breathing)運動による対称渦を伴う流れ方向の Movement-Induced-Excitation の単一励振域を呈する。

以下、それぞれについて説明する。

\section{2. 流れ方向強制加振円柱の後流渦のロックイン現象 ${ }^{1)}$}

図 1 は、 Griffin と Hall ${ }^{1)}$ による円柱を流れ方向に強制加 振した際の振幅 $2 \alpha D$ と強制振動数比 $f_{c} / f_{k}$ に対する円柱周 辺に生じる対称渦流れがロックインする領域 ${ }^{11)}$ - 14)をまと めて示したものである。 $f_{c} / f_{k}=2$ を中心として強制振動数 比の高低両側に円柱近傍に対称渦を伴うロックイン領域 


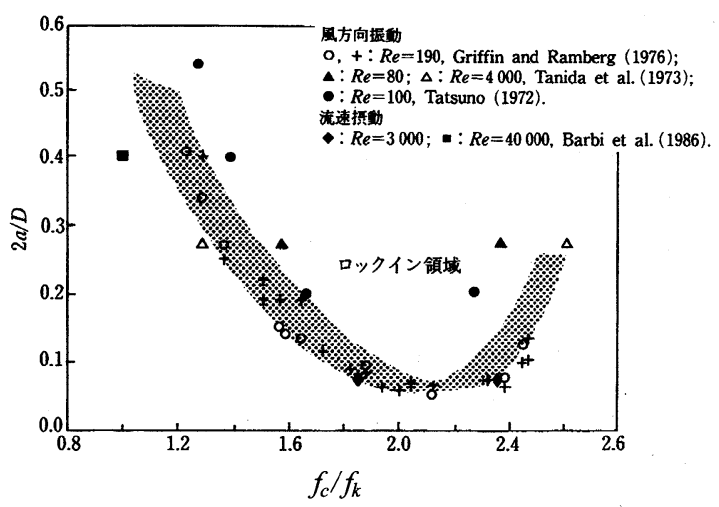

Fig.1, Rock-in region of an oscillating cylinder in the streamwise direction ${ }^{1)}$

が見られるが、この場合、 $f_{c} / f_{k}>2$ の早い振動数域（換算 流速表示で低い流速域) 側のロックイン領域が比較的狭い ことが注目される。また、レイノルズ数 Re $(=U d / v$ 、 $v$ は流体の動粘度) $=80 、 4 \times 10^{3}$ の流れ方向振動円柱に作用 する流体力測定例 ${ }^{12)}$ もるが、自由振動の応答特性とよく 対応する。元来、流れ方向の流体力(抗力)の変動分は、流 れに直角方向の流体力(揚力)の変動に比較して小さく、流 体力の振幅および位相の実験値を精度よく計測すること は容易ではない。そのため、精度のよい強制振動実験例は わずかである。

\section{3. 円柱の流れ方向流力振動特性 ${ }^{7)}$}

$\mathrm{King}^{2}$ 注水槽により円柱の流れ方向振動を調心゙、換算流 速 $V r$ が 1 2.5 の範囲と 2.6 3.6 の範囲で二つの励振域が 生じることを示した。その渦構造の観察から、最初の励振 域では主として対称渦が放出し、第 2 の励振域では交互渦 の放出を伴うことを述べた。岡島ら 励振に関する C. Scruton ${ }^{15)}$ の風洞実験と同じ方式で、一様 流中に剛体円柱が流れ方向に並進振動するように両端弾 性支持した場合の風洞実験を行った。その結果によれば、 King の実験結果と同様、共振流速、 $V r_{c r}=U /\left(f_{k} d\right)$ の半分、 $V r_{c r} / 2=2.5$ より低流速域の第 1 励振域 $(1.4<V r<2.5)$ と $V r_{c r} / 2$ 以上の第 2 励振域 $(2.6<V r<3.6) の 2 つ の$ 励振域が 存在する。そしてその振動特性は、図 2 に示すように、 $C n$ 值が大きくなるに従い2つの励振域の応答振幅はとも に減少するが、Cn 数に対してそれぞれ異なった振動特性 を示寸。 $V r_{c} / 2$ 以下の第 1 励振域の流れ方向変位の無次元 最大振幅值、 $\xi_{\text {max }}\left(=x_{\text {max }} / d 、 x_{\text {max }}\right.$ は円柱の流れ方向応答振 幅の $\mathrm{rms}$ 值の最大值) の変化は第 2 励振域に較心、 $C n$ 值 の増加によって $\xi_{\text {max }}$ の值は急激に減少する。そして、この

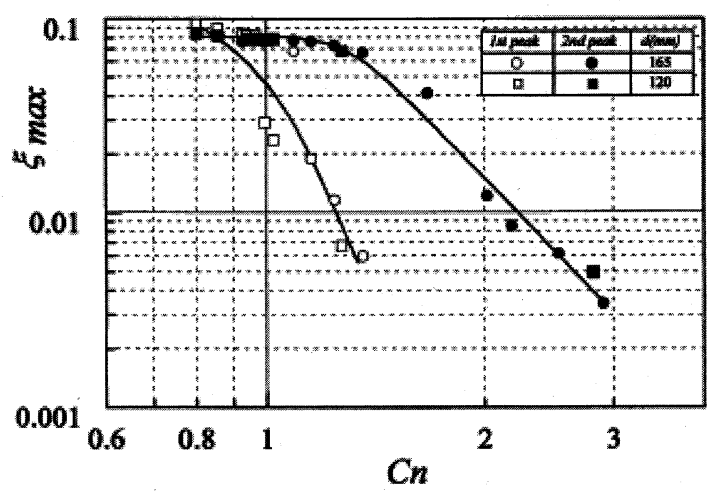

Fig.2, The maximum response amplitudes of a circular cylinder versus Scruton numbers ${ }^{\text {? }}$ )

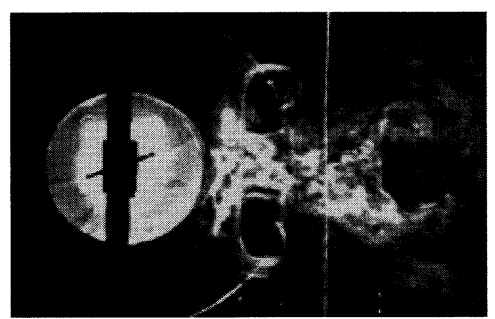

(a) Symmetrical vortices, $V r=2.3$ in the first excitation region.

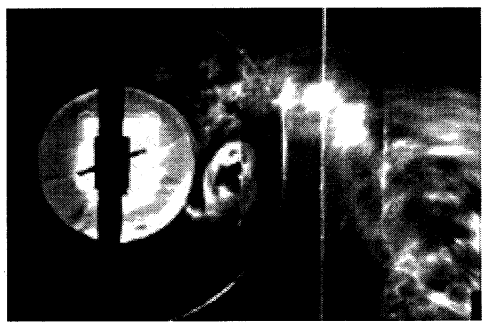

(b) Alternate vortices, $V r=3.2$, in the second excited region.

Fig.3, Flow-patterns around an oscillating cylinder ${ }^{7}, C n=0.77$.

時の振動円柱後流の代表的流れパターンを図 3 に示寸が、 $V r_{c} / 2$ 以下の第 1 励振域の $V r=2.3$ では、図(a) に示すよう に振動円柱近傍では上下対称の渦配置パターンが形成さ れ、 $V r_{c r} / 2$ 以上の第 2 励振域では図(b)に示すような交互渦 パターンが対応する。また第 2 励振域では後流渦の卓越ス トローハル数 $S t_{w}\left(=f_{w} d / U ; f_{w}\right.$ は後流渦の周波数 $)$ は、円柱 の強制振動数の半分、 $S t_{c} / 2$ に等しく、いわゆる後流渦の ロックイン(lock-in)現象が生じるが、第 1 励振域では下流 域の後流渦は非ロックイン(unlock)状態で、下流後流域の 周波数は自然発生渦の $S t_{n}\left(=f_{k} d / U\right)$ 成分が卓越する。こ のように $V r_{c r} / 2$ 付近前後の 2 つ流速域で生じる流れ方 向の励振にはそれぞれ振動特性に大きな相違が見られる。 特に、低速側の第 1 励振域における応答振幅、 $\xi_{\text {max }}$ は $C n$ 
值の増加に対して極めて急激に減衰するのに対し、高速側 の第 2 励振域の振動の $C n$ 値に対する $\xi_{\text {max }}$ の変化は比較的 緩慢で $C n$ 值が約 2.5 で $\xi_{\text {max }}$ の值は 0.05 程度の小振幅振動 まで減衰する。

\section{Aguirre $の$ 実験 ${ }^{4}$}

振動特性と対称渦の関係については、興味ある研究とし てNaudasherの解説”によって紹介された Aguirreの流れ方 向の流力振動の発生機構に関する水路実験がある。Aguirre は振動時の流れパターンと円柱の応答振幅の対応を詳細 に調べて示唆に富む知見を得ている。第 1 励振域の非ロッ クイン領域では、円柱の流れ方向振動に対応して円柱表面 から剥離した自由せん断層が接近したり離れたりして、後 流幅が対称な形で円柱の振動数に一致して変動し、いわゆ る後流の息づき(wake breathing)運動を呈する。この現象に 注目して、図4のように振動円柱背面から下流にスプリッ ター板 ( 直径の 13 倍の長さ) を挿入して下流域に交互 渦の形成を抑制した実験を行った。図には、自由振動する 円柱の周波数 $f$ と $f_{\mathrm{c}}$ の相違を $f_{\mathrm{c}} / f$ で示し、円柱の応答振幅 a/d を示す。図中、破線で示すスプリッター板のない場合 の応答と比較するが、第 1 励振域の大部分の領域では両者 ほとんど同様な特性を示し、対称渦パターンを呈する。す なわち、第 1 励振域の振動は、円柱下流域の後流渦による 影響が少なく、円柱運動自身により励起される後流の息が き運動に起因する自励振動によって生ずるものである。ま た、破線で示寸単独円柱の場合、 $V r=2.5$ 付近の急激な振 幅低下は、このような後流の息づき運動による対称渦に対

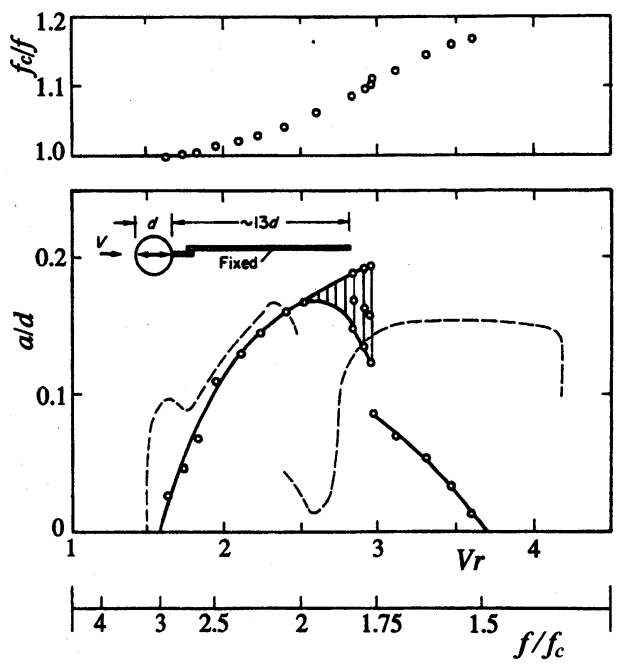

Fig.4, Results of Aguirre's experiments ${ }^{4)}$
し、Vr の増加に伴う交互渦の発生・成長による減衰効果 によるものと考えられる。また、池田 ${ }^{10}$ は、Aguirre によ る実験の第 1 励振域における後流渦構造において、a. 抗 力倍調和励振、 b. 後流渦再形成、 c. ロックインの $3 つ の$ 流れパターンがあり、渦構造と振動メカニズムの密接な関 係を説明している。

\section{5. アスペクト比の変化こよる振動特性》8)}

片端支持円柱において、アスペクト比を $A R=5 、 10 、 14$ 、 $21(C n=0.24 \sim 0.37)$ に変化させた場合の振動特性を 2 次元 円柱 $(C n=0.77)$ と比較して図 5 に示す。図から、いずれ も $V r=1.2 \sim 2.0$ の流速範囲ではほぼ一致した振動特性を 示すが、アスペクト比が最も小さい 5 の場合、 $V r=2.5$ の 高流速域まで振幅が急増し、 $V r=2.5 \sim 3.2$ の間では緩やか に応答振幅が減少して対称渦を伴う励振域を形成する。 すなわち、アスペクト比が 10 よりも小さい場合、第2 励 振域が消滅して単一励振域のみとなる。一方、アスペクト 比の大きい $A R=14 、 21$ の場合、 $V r=2.4$ 付近では振幅は 减衰して谷を形成し、再び増加して $V r=2.7$ 付近で最大振 幅となる第 2 励振域を形成する。アスペクト比によって最 も振動特性に差が見られるのは、 $V r=2.5 \sim 3.2$ の領域で、 2 次元円柱や $A R=14 、 21$ 円柱に見られる第 2 励振域であ り、この流速域がアスペクト比によって大きな影響を受け る。

次章以下、円柱近傍に形成される渦構造のスパン方向変 化に注目して、アスペクト比の影響について考察する。

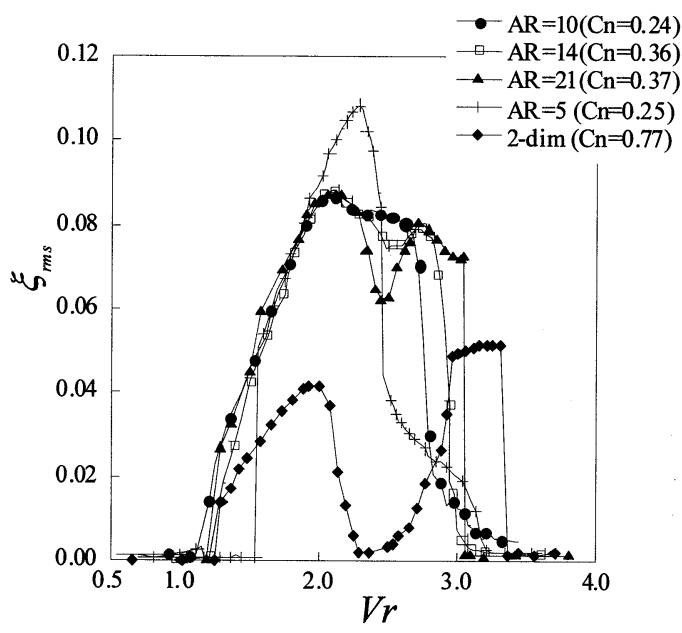

Fig.5. Response amplitudes of a cantilevered cylinder with different aspect ratios of 5 to $21^{8)}, C n=0.25$ 
6. 端板付きアスペクト比 21 振動円柱における洞構造の スパン方向変化 ${ }^{9)}$

図 6 に、中村らによるアスペクト比 $A R=21$ の円柱先端 に直径 $60 \mathrm{~mm}$ の端板をつけて端部の流れを抑制し、片持 ち弾性支持した円柱の換算流速 $V r$ に対寸る応答振幅 $\xi_{m s}$ を示す。この場合、先端部に端板を設置することにより 2 次元円柱の振動特性と同様な特性を呈する。そこで、図中、 矢印をつけた換算流速において、円柱背後に上下対称の位 置に設置した 2 本の熱線プローブによって計測した渦放 出周波数 $f_{w}$ および相互の位相差 $\psi$ の円柱先端を $z=0$ とし たスパン方向分布を図 7 に示す。図 6 の $V r=1.2 \sim 2.2$ は第 1 励振域、 $V r=2.3 \sim 2.4$ に谷を形成し、 $V r=2.5 \sim 3.2$ は第 2 励振域である。第 1 励振域の開始直後である図 7(a) $V r=$ 1.22 では、円柱近傍の渦は円柱の振動数の $1 / 4$ に同期して、 位相差が $180^{\circ}$ 近くの交互渦が観察される。第 1 励振域で 応答振幅が増加する途中である(c) $V r=1.79$ では、円柱の 先端から $1 / 3$ までの間は振動数に同期して位相差が $0^{\circ}$ 近 くの対称渦が生じている。これより根元側は静止円柱の力 ルマン渦放出周波数に近い周波数を持つ交互渦が生じて いる。応答振幅が第 1 励振域のピークに近い(d) $V r=2.01$ では、渦放出周波数は円柱の振動数の $1 / 2$ に近くなるが、 完全には同期せずに時間的に変動する不安定な状態とな る。応答振幅が急激に減衰する(e) $V r=2.24$ では、全スパ ンに亘ってロックインして円柱の振動数の $1 / 2$ に同期する 交互渦が形成される。応答振幅が急減して谷を形成する(f) $V r=2.40$ では、渦放出周波数が円柱の振動数の $1 / 2$ に同期 する交互渦が生じる。第 2 励振域の $V r=2.50 \sim 3.30$ の間で は、渦放出周波数は換算流速の影響をほとんど受けず、ス

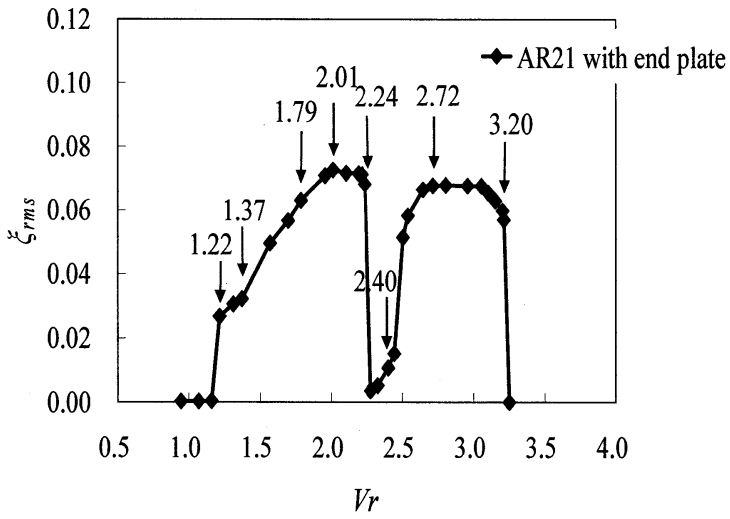

Fig. 6, Response amplitudes of the $A R 21$ cylinder with the end plate against reduced velocity at $C n=0.47^{9}$.

Arrows show the points when the vortex frequencies are measured.

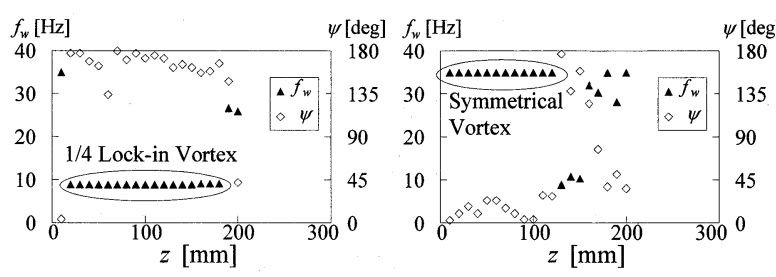

(a) $V r=1.22$

(b) $V r=1.37$

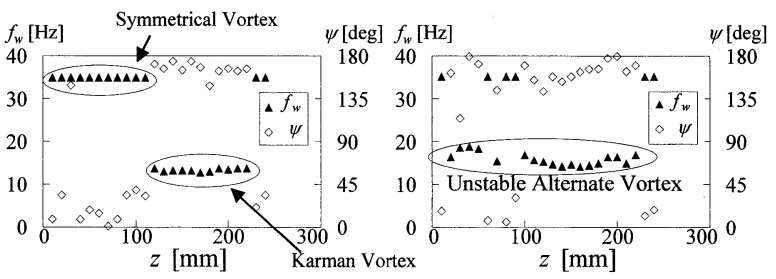

(c) $V r=1.79$

(d) $V r=2.01$

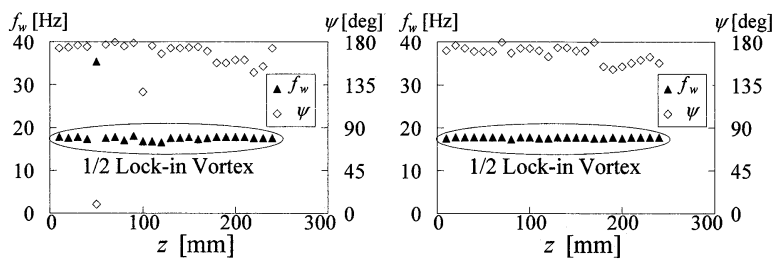

(e) $V r=2.24$

(f) $V r=2.40$

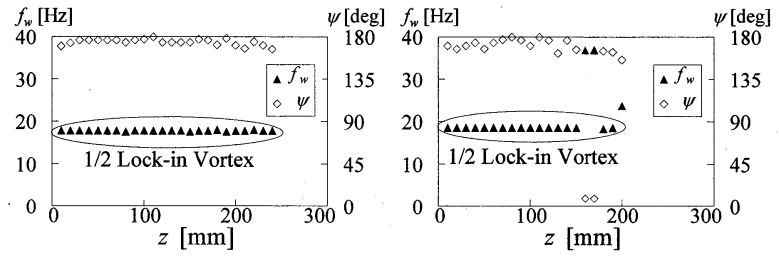

(g) $V r=2.72$

(h) $V r=3.20$

Fig.7 Frequencies of vortex shedding in the wake with the oscillating $A R 21$ cylinder with the end plate. ${ }^{9)}$

Table 1, Excitation regions and vortex structures against reduced velocity9)

\begin{tabular}{|c|c|c|c|c|c|}
\hline & $\begin{array}{l}\text { Reduced } \\
\text { velocity }\end{array}$ & $\begin{array}{l}\text { Oscillation } \\
\text { region }\end{array}$ & $\begin{array}{l}\text { Vortex } \\
\text { frequency }\end{array}$ & $\begin{array}{l}\text { Phase } \\
\text { difference }\end{array}$ & $\begin{array}{l}\text { Vortex } \\
\text { Structure }\end{array}$ \\
\hline (1) & $\mathrm{Vr} \fallingdotseq 1.2$ & \multirow{4}{*}{ First region } & $f_{c} / 4$ & $180^{\circ}$ & Alternate \\
\hline (2) & $1.4<\mathrm{Vr}<2.2$ & & $f_{c}$ & $0^{\circ}$ & Symmetrical \\
\hline (3) & $2.0<\mathrm{Vr}<2.2$ & & $f_{c} / 2$ & $180^{\circ}$ & \multirow{4}{*}{ Alternate } \\
\hline (4) & $2.2<\mathrm{Vr}<2.4$ & & Unstable & unstable & \\
\hline (5) & $2.4<\mathrm{Vr}<2.5$ & Valley & \multirow{2}{*}{$f_{c} / 2$} & \multirow{2}{*}{$180^{\circ}$} & \\
\hline (6) & $2.5<\mathrm{Vr}<3.2$ & Second region & & & \\
\hline
\end{tabular}


パン方向全体にロックインが生じて円柱の振動数の $1 / 2$ に 同期する交互渦が生じる。このように換算流速に対する変 化から、第 2 励振域はロックインが生じて交互渦のみであ ることに対して、第 1 励振域はより複雑な挙動を示す。こ こで最も興味深いことは、対称渦から交互渦への切り替わ りは、 $V r=2.0$ 付近で生じ、振幅が急减する谷の $V r=2.5$ 前後では、円柱振動数の $1 / 2$ にロックインして交互渦が放 出されている。従って円柱の応答振幅の急减は交互渦の形 成・成長によって生じる減衰特性によることがわかる。

表 1 には、上記に述べた端板付きスパン長さ 21 円柱の 後流瀜構造の変化を換算流速に対して整理して示す。この ような励振域と渦構造の関係は、Aguirre による結論とよ い一致を示す。

7. 有限スパン長さ（アスペクト比 $\boldsymbol{A R = 1 0 )}$ の振動円柱に おける渦構造のスパン方向変化 ${ }^{9)}$

次に、短い有限スパン長さ円柱の例として $A R=10$ の円 柱について換算流速に対する応答振幅変化を図 8 に示す。 円柱スパン長さが短い $A R=10$ の場合、眓のように $V r=1.2$ ３.2 の範囲で一つの励振域を形成し、谷がなくなる。図 8 中の矢印で示した換算流速におけるスパン方向の渦放 出周波数を図 9 (a)〜(d) に示す。(a) $V r=1.41$ の場合は、先 端から根元近傍まで渦放出周波数は円柱の振動数に同期 して位相差が $0^{\circ}$ に近く、対称渦が放出されている。端板 付き $A R=21$ 円柱の図 7(b) $V r=1.37$ の場合、先端 $(\mathrm{z}=0)$ から中央にかけて対称渦が放出されたことと異なる。図 9 (b) $V r=1.77$ の場合は、円柱先端近傍に円柱の振動数の $1 / 2$ に同期した渦が生じ、円柱の根元にかけて円柱の振動数に 同期した対称渦が見られる。端板付き $A R=21$ 円柱の図 7 (c) $V r=1.79$ の場合、円柱先端から中央までは対称渦、中央か ら根元では交互渦が形成されることに対し、 $A R=10$ 円柱で 交互渦が認められないことが注目される。端板付き $A R=21$ 円柱では、図 7(e) $V r=2.24$ からは対称渦が形成されないこ とに対し、 $A R=10$ 円柱では (c) $V r=2.19 、$ (d) 2.49 では対称 渦は先端部に形成され、中央から根元側に円柱の振動数の $1 / 2$ に同期する交互渦が生じる。すなわち、アスペクト比 が小さくスパン長さが短くなることによって対称渦形成 の流速範囲が広くなり、応答振幅が増大し、交互渦による 第 2 励振域が現れなくなる。このような 2 次元円柱の特性 に対し、 $A R=10$ 円柱の場合、先端部を越える流れにより交 互渦の発生が抑制され、図8 のように、対称渦による単一 の励振域を呈する。

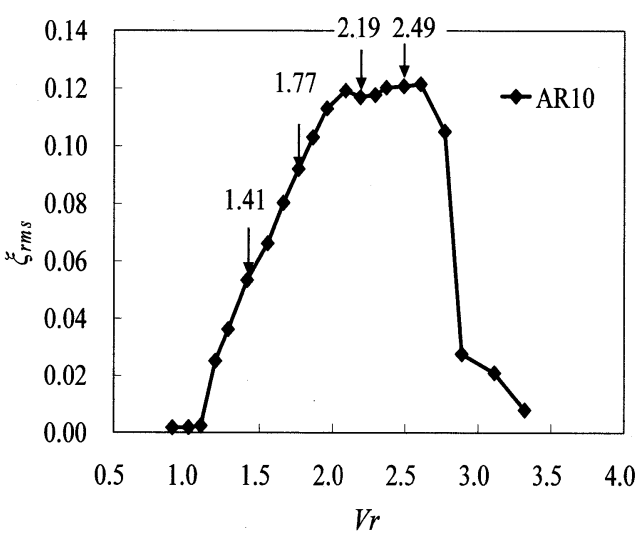

Fig.8, Response amplitudes of $A R 10$ cylinder against reduced velocity at $C n=0.20$. Arrows show the points when the vortex frequencies are measured ${ }^{9}$.

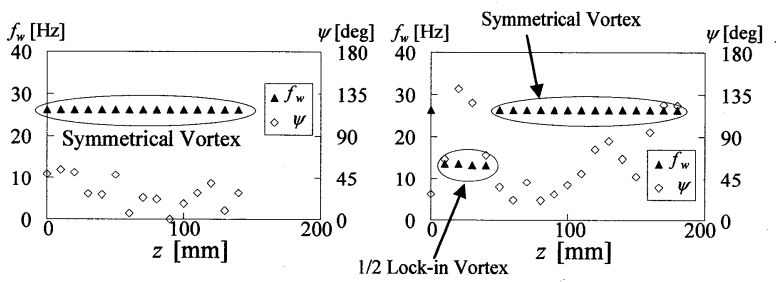

(a) $V r=1.41$

(b) $V r=1.77$

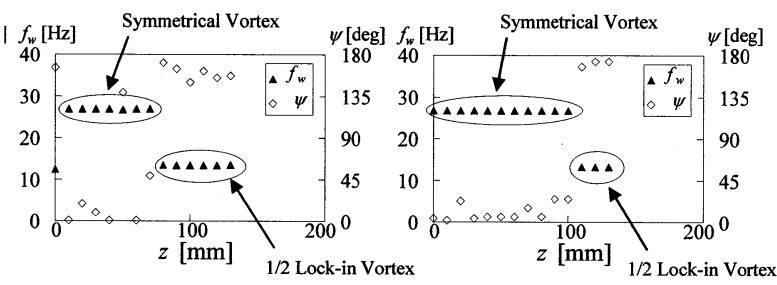

(c) $V r=2.19$

(d) $V r=2.49$

Fig.9. Frequencies of vortex shedding in the wake with the oscillating AR10 cylinder ${ }^{9}$

\section{8. 円柱後流にスプリッタープ板を設置したときの振動特 性 ${ }^{9)}$}

円柱後流の渦構造を変えたときの振動特性を調べるた め、図 10 のようにアスペクト比 $A R=10$ 円柱に直径 $60 \mathrm{~mm}$ の端板をつけた場合と後流に長さ $200 \mathrm{~mm}$ のスプリッター 板を挿入した。図 11 に、その流れ方向応答特性の実験結 果を比較して示す。端板は、円柱先端を回り込む流れを抑 制し、スプリッター板は後流を円柱の左右に分けて交互渦 の発生を抑制して対称渦による励振だけで振動する。いず れの場合もスクルートン数值は約 $C n=0.3$ である。 $A R=10$ 円柱が単一励振域を形成するのに対し、端板つき $A R=10$ 円柱は $V r=2.2 \sim 2.4$ の範囲で応答振幅が減少して谷が生 
じ、 $V r=2.5 \sim 3.3$ の範囲で第 2 励振域を形成する。一方、 スプリッター板を挿入した $A R=10$ 円柱では、 $V r=1.2 \sim 3.2$ の範囲で単一の励振域を形成する。この場合、通常の $A R=10$ 円柱に比べて振幅はさらに増大し、励振域が高流速 域へ拡大している。図 11 では、アスペクト比 10 円柱では 振動開始直後の $V r=1.2$ 近傍でスプリッター板を設置した 場合より応答振幅がわずかに増加する。この換算流速では 図 7(a)のように円柱の振動数の $1 / 4$ に同期する交互渦が生 じている。 $V r=1.2 \sim 2.0$ の範囲で応答振幅はいずれの場合 も一致し、対称渦を伴う励振であることが分かる。 $V r=2.0$ 〜2.2 の範囲では、スプリッター板設置による対称渦のみ 生ずる場合に較べ、いずれも振幅が小さくなる。スプリッ ター板がない場合、図 9(c), (d)のように先端部に対称渦が 形成され、根元に近い部分には円柱振動数の $1 / 2$ にロック インした交互渦が形成される。さらに端板つき $A R=10$ 円 柱では $V r=2.2 \sim 2.4$ の範囲でさらに振幅が小さくなる。こ のことから端板付き $A R=21$ 円柱で図 7(e),(f)のように、円 柱振動数の $1 / 2$ に同期する交互渦が有する流力特性によっ
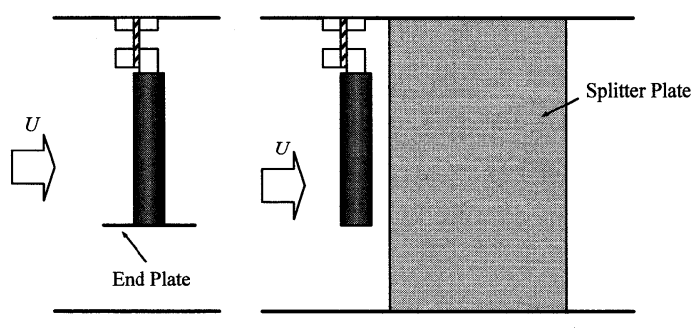

Fig.10, $A R 10$ cylinder with the end plate (left), and with the splitter plate in the wake (right) ${ }^{9}$.

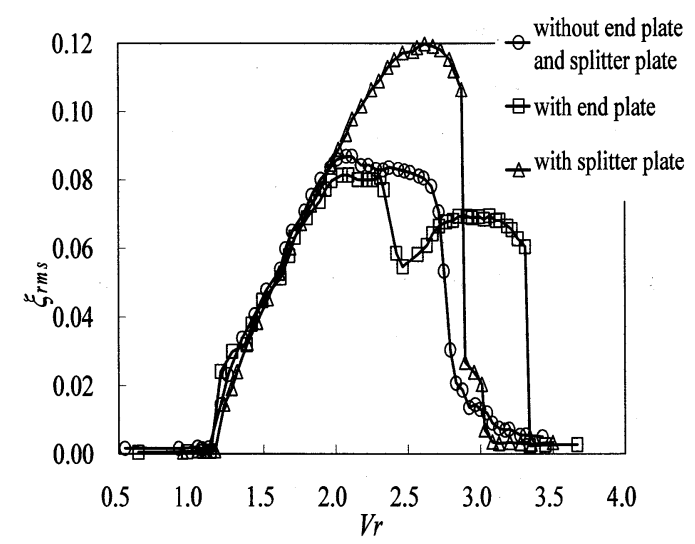

Fig.11, Response amplitudes of the $A R 10$ cylinder against reduced velocity ${ }^{9}$ : $O$ 、 without end plate and splitter plate; $\diamond$, with the end plate; $\triangle$,with the splitter plate.
て減衰し、応答振幅の谷が現れる。 $A R=10$ 円柱とスプリッ ター板を設置した $A R=10$ 円柱では、交互渦に比べて対称 渦を伴う励振が支配的であるため第 2 励振域が生じなく なる。一方、端板を設置すると流れの 2 次元性が増大し、 端板付き $A R=10$ 円柱は、 $A R=21$ 円柱と同様、 $V r=2.5 \sim 3.3$ の範囲で第 2 励振域を形成するようになる。この場合、図 7(g), (h) のように円柱振動数の $1 / 2$ に同期する交互渦によ る励振である。

\section{9. 狭い間隔 (円柱間隔 $s=0.3$ ) の直列 2 円柱の上流側円柱 の流れ方向流力振動 ${ }^{10)}$}

最後に、円柱下流側スプリッター板以外の物体を設置し た例として、直列 2 円柱の上流側円柱の流れ方向流力振動 特性を図 12 に示す。図は、2 月柱の無次元円柱間隔 $S(=S / d$ 、 $S$ は 2 円柱中心間隔) $s=0.3$ の場合の応答特性を○印で示 す。単独円柱の場合と同様に、 $V r=1.4$ 付近から振動が生 じ、 $V r=2.7$ 付近で最大振幅 $\xi_{m \mathrm{~m}}=0.057$ となり、その後、振 幅は急激に減衰する。しかし振動は完全に減衰せず、 $2.7<V r<3.2$ で $\xi_{m s}=0.015$ 程度で振動し、 $V r=V r_{c r} / 2(=3.25)$ で 振動がおさまる。またム印で示すストローハル数は、大き な励振が起こる $1.5<V r<2.7$ の範囲で $S t_{w}=S t_{c}$ と固有振動数 にロックインして、 $2.7<V r<3.2$ の小さな応答振幅の範囲で は、 $S t_{w}=S t_{c} 2$ になり円柱振動数の $1 / 2$ 倍にロックインする。 さらに振動がほとんじ減衰した高流速域の $V r>3.2$ では $S t_{w}=0.15 \sim 0.16$ で一定となり、静止直列 2 円柱におけるス トローハル数とほぼ一致する。図 13 は $s=0.3$ での換算流 速 $V r=2.36 、 2.90$ における円柱後流渦の可視化写真を示す。

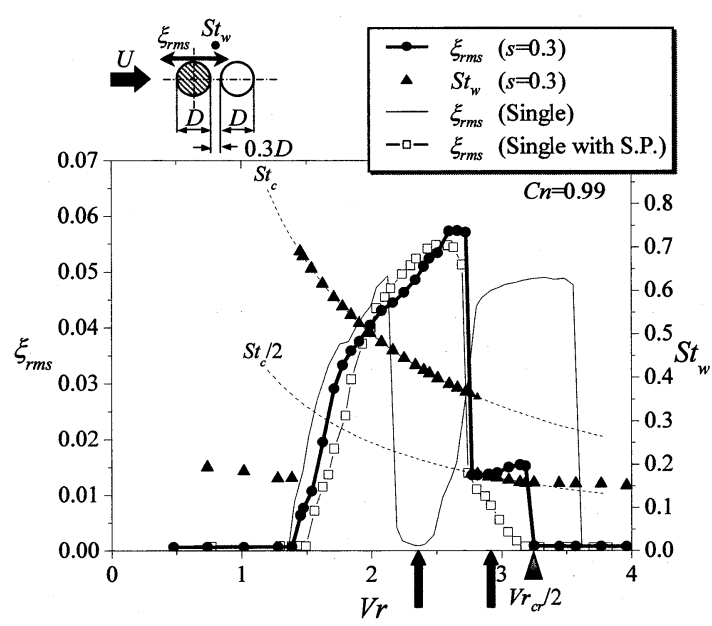

Fig.12, Response amplitudes of the upstream cylinder and Strouhal number for two circular cylinders in tandem arrangement of $C n=0.99$ and $s=0.3^{10)}$ 


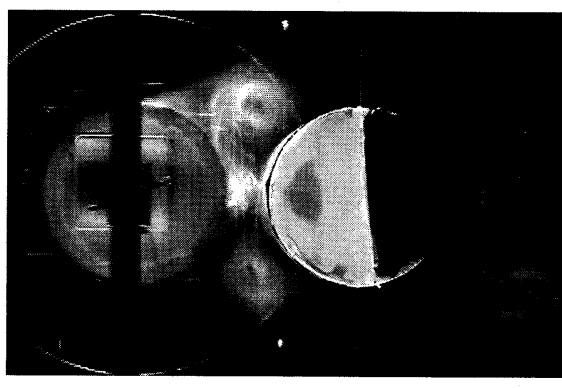

(a) $V r=2.36$

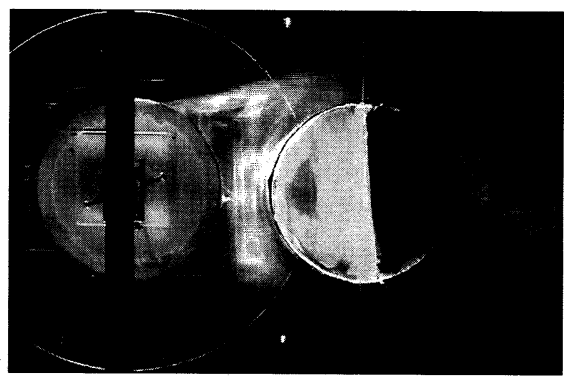

(b) $V r=2.90$

Fig.13, Visualized flow patterns around two circular cylinders in tandem arrangement of $C n=0.99$ and $s=0.3^{10)}$.

図 13 (a) $V r=2.36$ は、図 12 で示した励振のピーク付近の流 れパターンであり、 $1.4<V r<2.7$ の広い励振域で、上流側円 柱の上下側面から同時に剥離し、物体後流では円柱の固有 振動数にロックインした刘称渦パターンとなる。この励振 域は、対称渦を伴う Movement-Induced Excitationによって 生ずる。このように単独円柱に比べて第 1 励振域の流速域 が桩大し、最大応答振幅が大きくなる現象は、円柱間隔が 近い場合、上述した振動円柱後方にスプリッター板を設置 した場合と同様、下流側円柱が交互渦の発生を抑制し、対 称渦による振動を促進するスプリッター板効果によるも のである。次に、図 13 (b) $V r=2.90$ は、図 12 で、ピーク から一旦減衰した後、 $\xi_{m s}=0.015$ で振動している時の流れ の様相を示す。円柱間では死水域を形成し、死水域の流体 は上流側円柱の振動に一致して、下流側円柱背後に交互に 渦を形成・放出している。この渦は円柱の振動ストローハ 儿数 $S t_{c}$ の $1 / 2$ に同期している。

\section{0. 結論}

一様流中の円柱に生じる流力振動、特に流れ方向流力振 動の一部は、低流速域において対称渦によって励振が生じ る。本報では、振動する円柱の近傍に形成される対称渦に 注目してその渦構造と円柱の流れ方向流力振動について 述べた。柱の流れ方向振動に呼応して円柱表面から剥離 した自由せん断層が接近したり離れたりして、後流幅が対
称な形で円柱の振動数に同期して変動し、いわゆる後流の 息づき(wake breathing)運動を呈して対称渦が形成される。 流れ方向振動の第 1 励振域では、対称渦による Movement-Induced Excitationによって応答振幅は増大する が、丁度、共振流速の $1 / 2$ より低い流速域から始まる円柱 下流域に形成される交互渦の減衰効果によって共振流速 の $1 / 2$ 付近で応答振幅は極端に低下寸る。そして有限ス パン長さ円柱ではスパン方向には交互渦と対称渦が混合 して形成されるので、渦構造の相違による励振の様相は複 雑である。そこで、種々なアスペクト比の有限スパン長円 柱の流れ方向の流力振動特性と渦構造分布に注目して、振 動円柱の渦構造のスパン方向変化をアスペクト比による 相違など詳細に調べて励振機構との関係を明らかにした。

さらに、下流にスプリッター板を挿入することにより対 称渦形成を促進して円柱の流れ方向励振域の桩大と応答 振幅の増大を確認した。

振動円柱の下流域に挿入した物体効果は、直列に配置さ れた 2 円柱の場合、狭い間隔の上流側円柱の流力特性にも 現れる。直列 2 円柱の上流側円柱の応答特性には、低い流 速領域で対称渦を伴う流れ方向の Movement-InducedExcitation による単一励振域が現れる。このような対称渦 を伴う物体の励振は、管群など下流域に他の物体によって 交互渦の形成が抑制される際に現れ易いことは注目され る。

\section{参考文献}

1) Griffin, O.M. and Hall, M.S., "Review--Vortex shedding Lock-on and flow control in bluff body wakes", J. Fluids Eng., Trans. ASME, 113, pp.526-536, 1991-12.

2) King. R., Prosser. M. J. and Johns, D. J., "On Vortex Excitation of Model Piles in Water", Journal of Sound and Vibration, 292, pp.169-188, 1973.

3) Naudasher, E., "Flow-induced streamwise vibrations of structures", Journal of Fluid and Structures, 1 pp.265-298, 1987.

4) Aguirre, J. E., "Flow-Induced, In-line Vibrations of a Circular Cylinder", Doctoral Dissertation, Imperial College of Science and Technology, London, 1977.

5）岡島厚、大津山澄明、永森稔朗、中野智仁、木綿隆弘、 “円柱および矩形柱の流れ方向流力振動特性”、日本機 械学会論文集 B65-635, pp.2196〜2203, 1999

6) Okajima, A., Kosugi, T., Nakamura, A, "Flow-Induced In-Line Oscillation of a Circular Cylinder in a Water Tunnel", American Society of Mcchanical Enginccrs, Journal of 
Pressure Vessel Technology, 124, pp.89 96, 2002.2.

7) Okajima, A., Nakamura, A., Kosugi, T., Uchida, H., Tamaki, R., "Flow-Induced In-Line Oscillation of a Circular Cylinder", European Journal of Mechanics, B 23, pp.115 125, 2004.2.

8) Nakamura, A., Okajima, A., and Kosugi, T., "Experiments on Flow-Induced In-Line Oscillation of a Circular Cylinder in a Water Tunnel (2nd Report, Influence of the Aspect Ratio of a Cantilevered Circular Cylinder)", JSME International Journal, Fluids and Thermal Engineering, B44-4, pp.705-711, 2001-11.

9) 中村晶、岡島厚、玉城怜士、木綿隆弘、“流れ方向振動 する有限スパン長さ円柱周りの流れイスパン方向の渦周 波数分布)”、日本機械学会論文集、B71-707,pp.1813-1820, 2005.

10) Okajima, A., Yasui, S., Kiwata, T., Kimura, S., 'Flow-Induced Streamwise Oscillation of Two Circular Cylinders in Tandem Arrangement', International Journal of Heat and Fluid Flow 28, pp.552-560, 2007.

11) Griffin, O. M. and Ramberg, S. E., "On vortex strength and drag in bluff body wakes," Journal Fluid Mechanics, 69, pp.721-728, 1975.

12) Tanida, Y., Okajima, A., Watanabe, Y., "Stability of a circular cylinder oscillating in uniform flow or in a wake", Journal of Fluid Mechanics, 61-4, pp.769-784, 1973.

13)辰野正和, “流れ方向に振動する円柱後方の渦列”, 九州 大学応応用力学研究所所報,36, pp.25-37, 1972.

14) Barbi, C., Favier, D.P., Maresca, C.A. and Telionis, D.P., "Vortex shedding and lock-on of a circular cylinder in oscillatory flow”, J. Fluid Mech.,vol.170,pp.527-544, 1986.

15) Scruton, C., "On the Wind-excited Oscillations of stacks, towers and masts", Proc. Intern. Conf. Wind Effects on Build \& Structures (Teddington), Her Majesty's Stationary Office, 1963.

16）池田孝志、“流れ方向流力振動に関する対称渦放出と 後流周波数の関係”、日本原子力学会誌、43-10、2001. 